Supporting Information

\title{
Host-guest chemistry for simultaneous imaging of endogenous alka- li metals and metabolites with mass spectrometry
}

Leonidas Mavroudakis, Kyle D. Duncan ${ }^{\dagger}$, Ingela Lanekoff*

${ }^{*}$ Corresponding Author

Ingela Lanekoff - Department of Chemistry - BMC, Uppsala University, Uppsala 75124, Sweden; orcid.org/0000-0001-9040-3230 Email: ingela.lanekoff@kemi.uu.se

Authors

Leonidas Mavroudakis - Department of Chemistry - BMC, Uppsala University, Uppsala 75124, Sweden; orcid.org/0000-0002-6520-3437

Kyle D. Duncan - Department of Chemistry - BMC, Uppsala University, Uppsala 75124, Sweden; orcid.org/0000-0003-0575-0858

Present Addresses

†Kyle D. Duncan - Department of Chemistry, Vancouver Island University, British Columbia, V94 5S5, Canada 


\section{Table of Contents}

Preparation of $\mathrm{NaCl}$ spiked mimetic tissue model

Exclusion of tissue holes after imaging and $\mathrm{ROI}$ of $\mathrm{NaCl}$ spiked mimetic tissue model

Extraction of ROI data from $\mathrm{NaCl}$ spiked mimetic tissue model

Calculation of theoretical equilibrium concentrations for crown ether adducts with $\mathrm{Na}^{+}$and $\mathrm{K}^{+}$

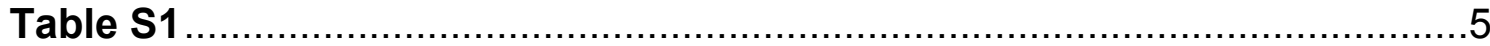

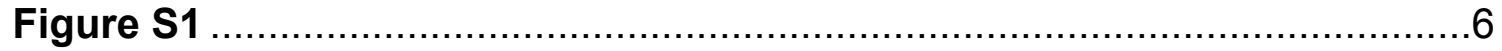

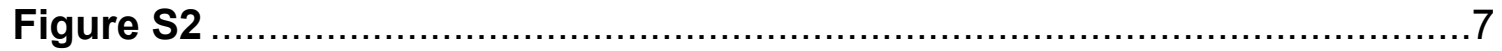

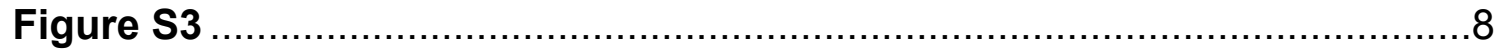

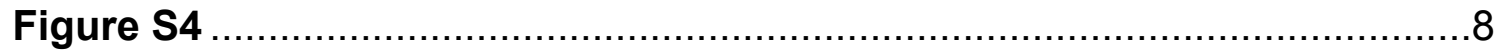

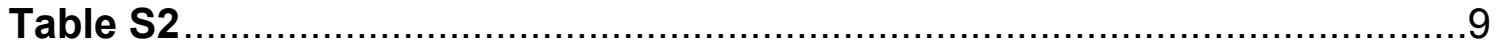

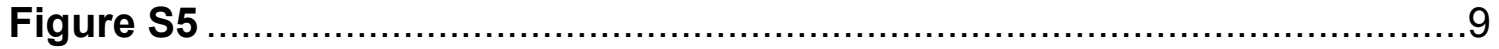

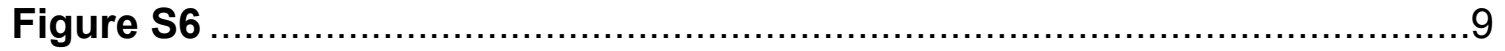

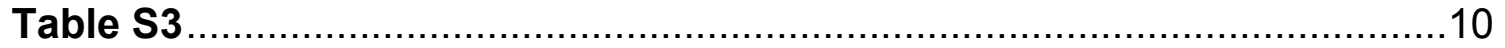

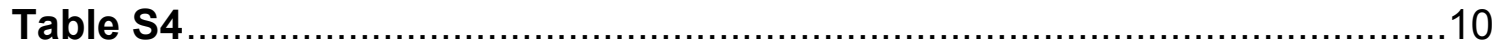

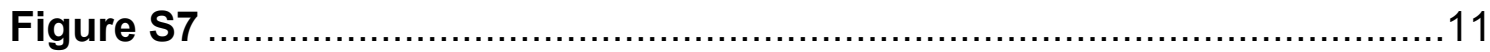

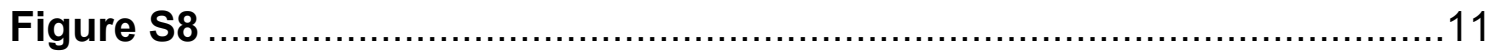

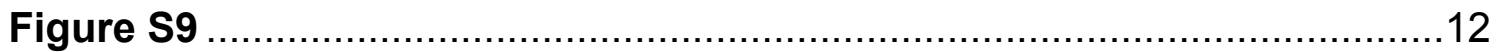

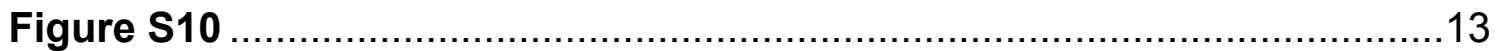

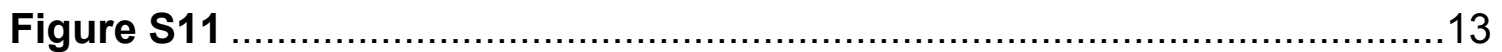

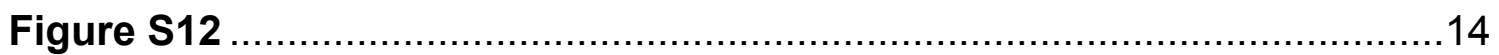

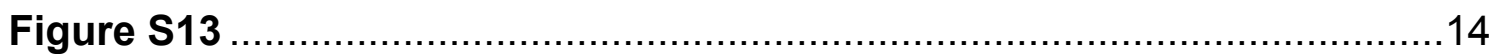




\section{Preparation of $\mathrm{NaCl}$ spiked mimetic tissue model}

Two rat brains were chopped, and pieces were distributed into $2 \mathrm{~mL}$ tubes containing $1.4 \mathrm{~mm}$ ceramic spheres (Lysing Matrix D, MPBio) for homogenization with a bead homogenizer (FastPrep-24, MPBio) at $4 \mathrm{~m} \mathrm{~s}^{-1}(30 \mathrm{~s})$ and for 2-3 rounds. All homogenates were combined into one tube, the pooled homogenates were aliquoted and the mass of each aliquot was recorded $(0.227-0.284 \mathrm{~g})$. For spiking each aliquot of homogenate, a concentrated aqueous $\mathrm{NaCl}$ solution was added to a final $\mathrm{Na}^{+}$concentration of 20,50 and $90 \mu \mathrm{mol} \mathrm{g}^{-1}$. The amount of spiked solution in each tissue homogenate was below $2 \% \mathrm{v} / \mathrm{v}$. One aliquot of brain homogenate was not spiked with $\mathrm{NaCl}$. To differentiate the different layers during mass spectrometric analysis, non-endogenous markers were spiked at known concentrations. Specifically, the non-spiked layer contained $24.5 \mu \mathrm{M}$ of diclofenac, the $20 \mu \mathrm{mol} \mathrm{g}^{-1} \mathrm{Na}^{+}$layer had $28.2 \mu \mathrm{M}$ of enalapril, the $50 \mu \mathrm{mol} \mathrm{g}^{-1} \mathrm{Na}^{+}$layer had $55.7 \mu \mathrm{M}$ phosphatidylethanolamine (PE) 30:0, and the $90 \mu \mathrm{mol} \mathrm{g}^{-1} \mathrm{Na}^{+}$layer had 33.8 $\mu \mathrm{M}$ of GABA-15N. The amount of spiked solution in each tissue homogenate was below $0.8 \% \mathrm{v} / \mathrm{v}$. Although mass spectrometric signals from diclofenac and PE 30:0 were not observed, the detection of enalapril and GABA- ${ }^{15} \mathrm{~N}$ enabled the region of interest analysis of all layers in the mimetic tissue model. All homogenates; spiked and non-spiked; were individually mixed in the bead homogenizer for $30 \mathrm{~s}$ at $4 \mathrm{~m} \mathrm{~s}^{-1}$. The homogenates were stored at $-80^{\circ} \mathrm{C}$ until use. The mimetic tissue model, containing different layers of $\mathrm{NaCl}$-spiked brain homogenate, was prepared by using a $3 \mathrm{~mL}$ plastic syringe which was modified and used as a mold. First, the non-spiked homogenate was added carefully in the syringe mold $(\approx 300 \mu \mathrm{L})$ and immediately frozen in dry-ice chilled ethanol. Then, the syringe mold was taken out of the cold ethanol and quickly the lowest $\mathrm{NaCl}$ spiked homogenate was added on top of the previous homogenate layer, dipped in cold ethanol for freezing and the process is repeated until all layers have been added. Care was taken for the layers not to mix with each other during the process which can be caused if they start to warm up. This resulted in a mimetic tissue model where the lowest layer is the nonspiked followed by the 20,50 and $90 \mu \mathrm{mol} \mathrm{NaCl} \mathrm{g}{ }^{-1}$.

\section{Exclusion of tissue holes after imaging and $\mathrm{ROI}$ of $\mathrm{NaCl}$ spiked mimetic tissue model}

Tissue irregularities caused during the preparation of the mimetic tissue model i.e. holes, were removed programmatically using a mask that differentiates tissue and non-tissue areas. This mask was created by selecting pixels from the optical image of the tissue section that have summed red-green-blue (RGB) triplet less than 700 . This threshold value was determined empirically and was based on the observation that the tissue area and the glass area (i.e. nontissue area) have distinct differences in their RGB triplets. Subsequently, for image generation and $\mathrm{ROI}$ analysis only data that corresponded to tissue area were considered.

\section{Extraction of ROl data from $\mathrm{NaCl}$ spiked mimetic tissue model}

To further assess the accuracy of the obtained intensity ratio for quantitative analysis of [ $\left.\mathrm{Na}^{+}\right]$, region of interest (ROI) analysis was performed. The ion image of endogenous [LPC 16:0 + $\mathrm{Na}^{+}$normalized to [LPC 19:0 $\left.+\mathrm{Na}\right]^{+}$is shown in Figure S9A to demonstrate observed tissue holes. These holes will impact the variation of the extracted ROI data and thus they were excluded during the analysis, as described in the section above. The $\mathrm{Na}^{+} / \mathrm{K}^{+}$adduct intensity ratio image of db18c6 before removing tissue holes programmatically is shown in Figure S9B. The constant supply of db18c6 through the nano-DESI solvent makes the visualization of the different layers difficult. To facilitate $\mathrm{ROI}$ selection, a composite ion image of [enalapril $+\mathrm{K}]^{+}$ and $\left[\mathrm{GABA}-{ }^{-15} \mathrm{~N}+\mathrm{Na}\right]^{+}$was used as indicator of the 20 and $90 \mu \mathrm{mol} \mathrm{g}^{-1}$ layers, respectively 
(Figures S9C, S9E \& S9G). The ROI for the non-spiked layer was selected based on the distribution of endogenous [creatine $+\mathrm{K}]^{+}$(Figure S9D). Finally, the ROI for the $50 \mu \mathrm{mol} \mathrm{g}^{-1}$ layer was selected based on the absence of any signal in that tissue area (Figure S9F).

\section{Calculation of theoretical equilibrium concentrations for crown ether adducts with $\mathrm{Na}^{+}$and $\mathrm{K}^{+}$}

Let $\mathrm{M}$ be the crown ether molecule, $(\mathrm{M}+\mathrm{Na})^{+},(\mathrm{M}+\mathrm{K})^{+}$the crown ether adducts with $\mathrm{Na}^{+}$and $\mathrm{K}^{+}$, respectively, and $\left[(\mathrm{M}+\mathrm{Na})^{+}\right],\left[(\mathrm{M}+\mathrm{K})^{+}\right]$the equilibrium concentrations of the complexes with sodium and potassium ions, respectively For the calculation of $\left[(\mathrm{M}+\mathrm{Na})^{+}\right]$and $\left[(\mathrm{M}+\mathrm{K})^{+}\right]$we consider a system of one crown ether where both $\mathrm{Na}^{+}$and $\mathrm{K}^{+}$are present simultaneously. In the experiment presented in Figure 1B, all four crown ethers were present simultaneously in the solution along with $\mathrm{Na}^{+}$and $\mathrm{K}^{+}$ions. However, the competition for sodium and potassium ions among the crown ethers is negligible when $[\mathrm{M}]<<\left[\mathrm{Na}^{+}\right],\left[\mathrm{K}^{+}\right]$.

$$
\begin{gathered}
M+N a^{+} \leftrightarrow(M+N a)^{+} \\
M+K^{+} \leftrightarrow(M+K)^{+}
\end{gathered}
$$

For the reactions (1) and (2), in equilibrium, we can write the respective equilibrium expressions, termed as binding affinity, $K_{b}$ :

$$
\begin{aligned}
K_{b, N a} & =\frac{\left[(M+N a)^{+}\right]}{[M]_{f}\left[N a^{+}\right]_{f}}(\mathbf{3}) \\
K_{b, K} & =\frac{\left[(M+K)^{+}\right]}{[M]_{f}\left[K^{+}\right]_{f}}(\mathbf{4})
\end{aligned}
$$

Where $[\mathrm{M}]_{\mathrm{f}}$ is the free crown ether concentration and $\left[\mathrm{Na}^{+}\right]_{\mathrm{f}},\left[\mathrm{K}^{+}\right]_{\mathrm{f}}$ are the free sodium and potassium concentrations, respectively.

According to mass balance equations:

$$
\begin{gathered}
{[M]_{T}=[M]_{f}+\left[(M+N a)^{+}\right]+\left[(M+K)^{+}\right]} \\
{\left[N a^{+}\right]_{T}=\left[N a^{+}\right]_{f}+\left[(M+N a)^{+}\right](6)} \\
{\left[K^{+}\right]_{T}=\left[K^{+}\right]_{f}+\left[(M+K)^{+}\right](7)}
\end{gathered}
$$

Where $[\mathrm{M}]_{T},\left[\mathrm{Na}^{+}\right]_{T}$ and $\left[\mathrm{K}^{+}\right]_{\mathrm{T}}$ are the total concentrations of crown ether, sodium and potassium, respectively.

Substitution of $[\mathrm{M}]_{\mathrm{f}},\left[\mathrm{Na}^{+}\right]_{\mathrm{f}}$ and $\left[\mathrm{K}^{+}\right]_{\mathrm{f}}$ from equations (5), (6) and (7) in equations (3) and (4) results in two independent equations where $\left[(\mathrm{M}+\mathrm{Na})^{+}\right]$and $\left[(\mathrm{M}+\mathrm{K})^{+}\right]$can be determined provided that $\left[\mathrm{M}_{\mathrm{T}},\left[\mathrm{Na}^{+}\right]_{T},\left[\mathrm{~K}^{+}\right]_{\mathrm{T}}, \mathrm{K}_{\mathrm{b}, \mathrm{Na}}\right.$ and $\mathrm{K}_{\mathrm{b}, \mathrm{K}}$ are known. The two equations used for calculating $\left[(\mathrm{M}+\mathrm{Na})^{+}\right]$and $\left[(\mathrm{M}+\mathrm{K})^{+}\right]$are shown below:

$$
\begin{gathered}
{\left[(M+N a)^{+}\right]^{2}-\left(\frac{1}{K_{b, N a}}+[M]_{T}+\left[N a^{+}\right]_{T}-\left[(M+K)^{+}\right]\right)\left[(M+N a)^{+}\right]+[M]_{T}\left[N a^{+}\right]_{T}} \\
-\left[N a^{+}\right]_{T}\left[(M+K)^{+}\right]=0(8)
\end{gathered}
$$




$$
\begin{gathered}
{\left[(M+K)^{+}\right]^{2}-\left(\frac{1}{K_{b, K}}+[M]_{T}+\left[K^{+}\right]_{T}+\left[(M+N a)^{+}\right]\right)\left[(M+K)^{+}\right]+[M]_{T}\left[K^{+}\right]_{T}} \\
-\left[K^{+}\right]_{T}\left[(M+N a)^{+}\right]=0(9)
\end{gathered}
$$

For example, the theoretical abundances calculated in Figure 1B were obtained by using $[\mathrm{M}]_{T}=0.1 \mu \mathrm{M},\left[\mathrm{Na}^{+}\right]_{T}=550 \mu \mathrm{M},\left[\mathrm{K}^{+}\right]_{\mathrm{T}}=550 \mu \mathrm{M}$ and the corresponding binding affinities $K_{b, N a}, K_{b, K}$ for each crown ether (see Table S2). The two nonlinear simultaneous equations ( 8 and 9 ) were solved numerically using MATLAB's vpasolve function, which provides the solutions for unknowns $\left(\left[(\mathrm{M}+\mathrm{Na})^{+}\right]\right.$and $\left.\left[(\mathrm{M}+\mathrm{K})^{+}\right]\right)$. Equations (8) and (9) give three solutions each, however, certain solutions were discarded if the following conditions were met:

$\left[(\mathrm{M}+\mathrm{Na})^{+}\right]>[\mathrm{M}]_{\mathrm{T}}$ or $\left[(\mathrm{M}+\mathrm{Na})^{+}\right]>\left[\mathrm{Na}^{+}\right]_{\mathrm{T}}$ or $\left[(\mathrm{M}+\mathrm{Na})^{+}\right]<0$

$\left[(\mathrm{M}+\mathrm{K})^{+}\right]>[\mathrm{M}]_{\mathrm{T}}$ or $\left[(\mathrm{M}+\mathrm{K})^{+}\right]>\left[\mathrm{K}^{+}\right]_{\mathrm{T}}$ or $\left[(\mathrm{M}+\mathrm{K})^{+}\right]<0$

Table S1. Concentrations and $\%{ }^{15} \mathrm{~N}$ enrichment of each ${ }^{15} \mathrm{~N}$-labelled amino acid originating from the obtained 12000 -times diluted cell free ${ }^{15} \mathrm{~N}$-labelled amino acids standard mixture that was added to the nano-DESI solvent as internal standards for quantitative imaging.

\begin{tabular}{|l|r|r|}
\hline Amino acid & \% $^{15} \mathbf{N}$ enrichment & Concentration $(\boldsymbol{\mu} \mathbf{M})$ \\
\hline Glutamic acid & 99.3 & 4.00 \\
\hline Aspartic acid & 99.3 & 7.00 \\
\hline Arginine & 99.3 & 1.25 \\
\hline Histidine & 99.3 & 0.42 \\
\hline Lysine & 99.3 & 1.42 \\
\hline Asparagine & 99.3 & 7.00 \\
\hline Cysteine & 998.2 & 1.67 \\
\hline Glutamine & 98.7 & 1.67 \\
\hline Methionine & 99.3 & 0.67 \\
\hline Serine & 99.3 & 2.42 \\
\hline Threonine & 99.3 & 2.75 \\
\hline Phenylalanine & 99.3 & 1.67 \\
\hline Tryptophan & 95.5 & 1.67 \\
\hline Tyrosine & 99.3 & 0.83 \\
\hline Alanine & 99.3 & 6.25 \\
\hline Leucine & 99.3 & 3.75 \\
\hline Isoleucine & 99.3 & 2.33 \\
\hline Valine & 99.3 & 3.00 \\
\hline Glycine & 99.3 & 4.83 \\
\hline Proline & 99.3 & 1.67 \\
\hline
\end{tabular}



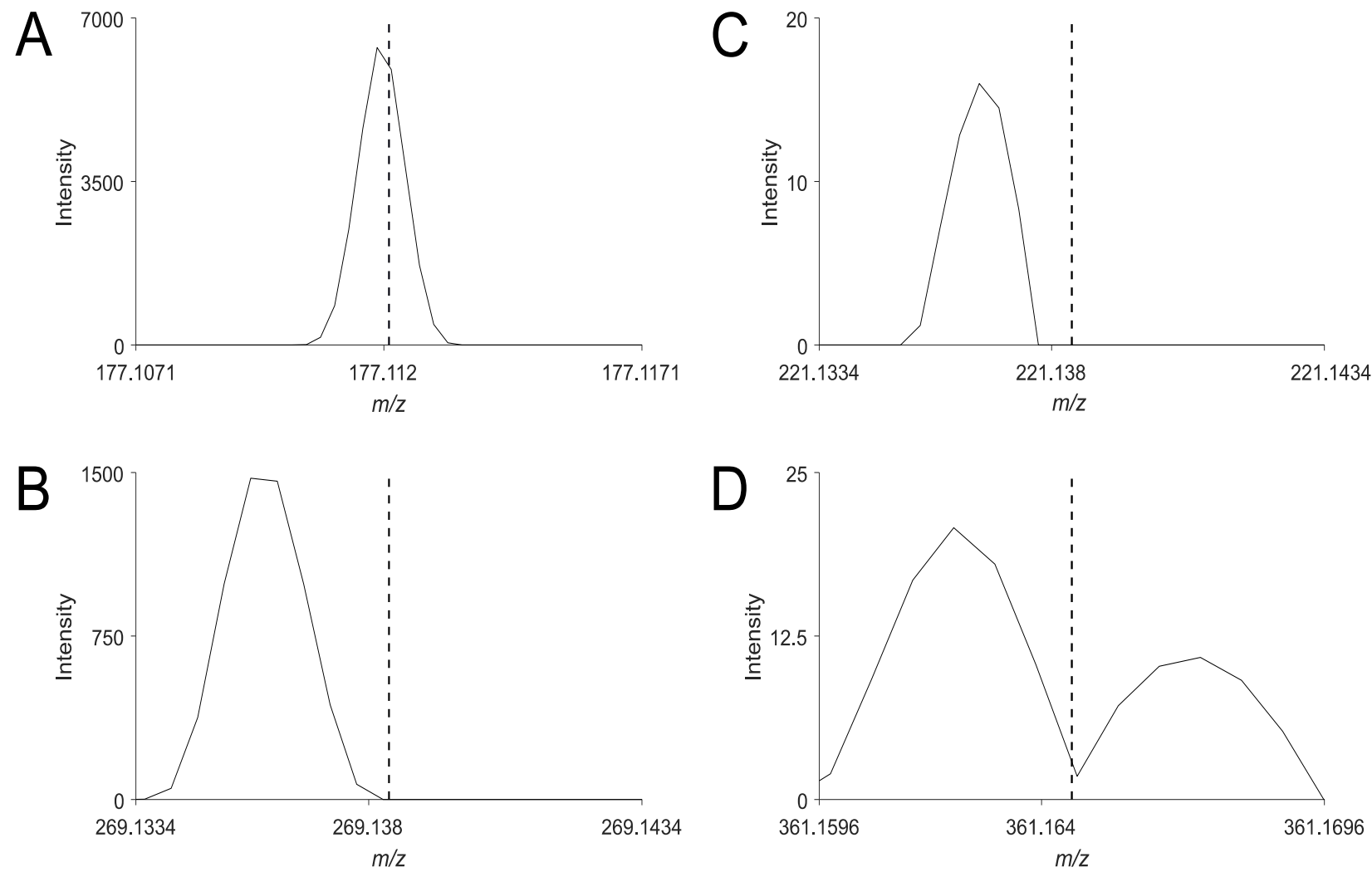

Figure S1. Expected $\mathrm{m} / \mathrm{z}$ ranges for protonated adducts of the tested crown ethers; A)12c4, B) b15c5, C) 15c5, D) db18c6 when a solution containing $250 \mu \mathrm{M} \mathrm{Na}^{+}, 250 \mu \mathrm{M} \mathrm{K}^{+}$and $0.1 \mu \mathrm{M}$ of each crown ether was analyzed with nano-DESI. Dashed lines indicate the theoretical $\mathrm{m} / \mathrm{z}$ for each protonated adduct, showing that only the $12 \mathrm{c} 4$ in A) generates a protonated adduct. 

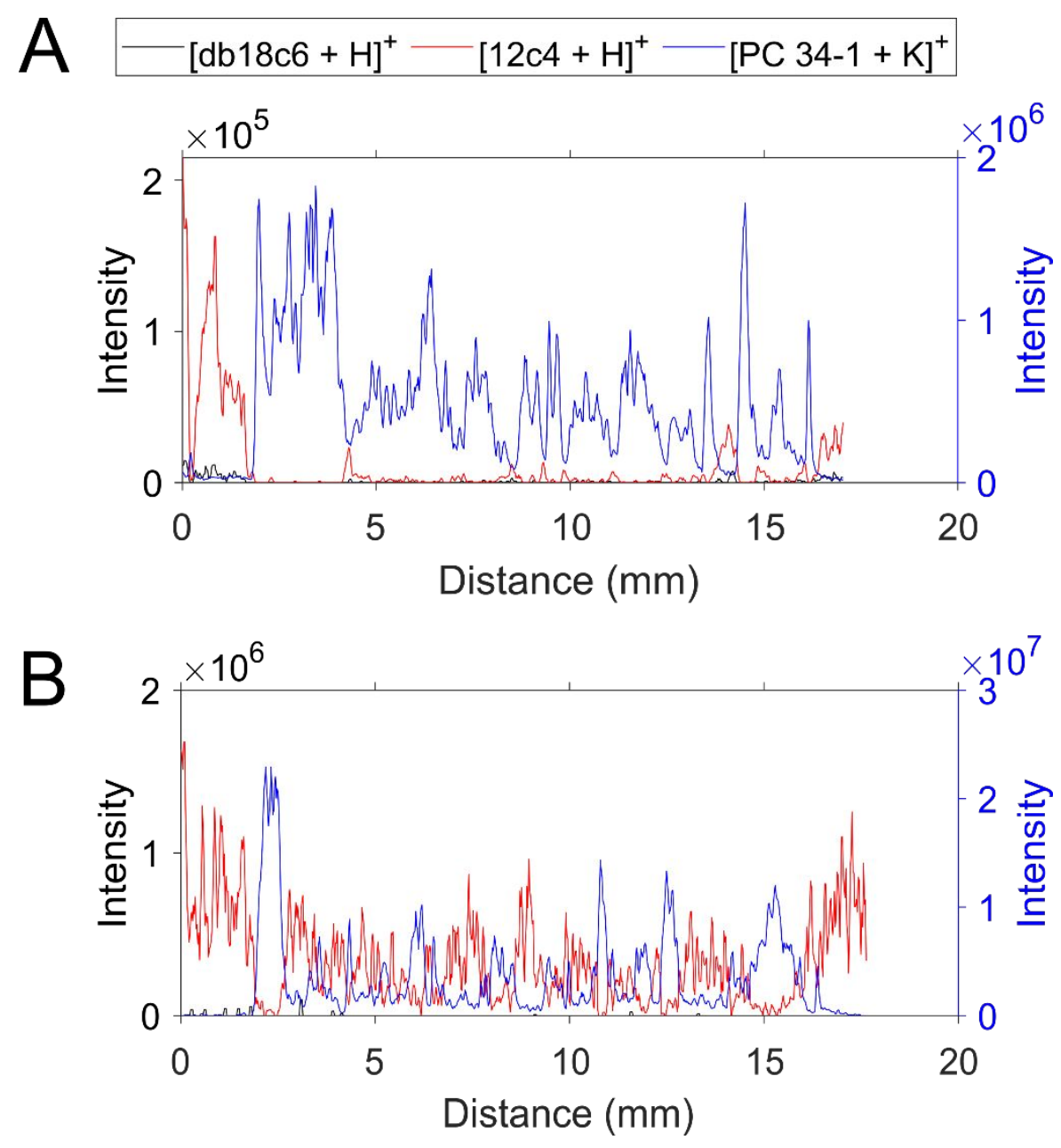

Figure S2. Line scan acquired over the sodium-spiked mimetic tissue model with nano-DESI MS where the solvent was A) $\mathrm{MeOH}: \mathrm{H}_{2} \mathrm{O}$ 9:1 v/v and $\mathrm{B}$ ) $\mathrm{MeOH}: \mathrm{H}_{2} \mathrm{O}$ 9:1 $\mathrm{v} / \mathrm{v}$ spiked with $0.1 \%$ formic acid. Traces for protonated adducts of db18c6 (black line) and 12c4 (red line) are shown with the corresponding intensities depicted on the left $y$-axis. Trace for endogenous potassiated PC 34:1 from the mimetic tissue model (blue) is also shown with the corresponding intensity on the right $y$-axis. 


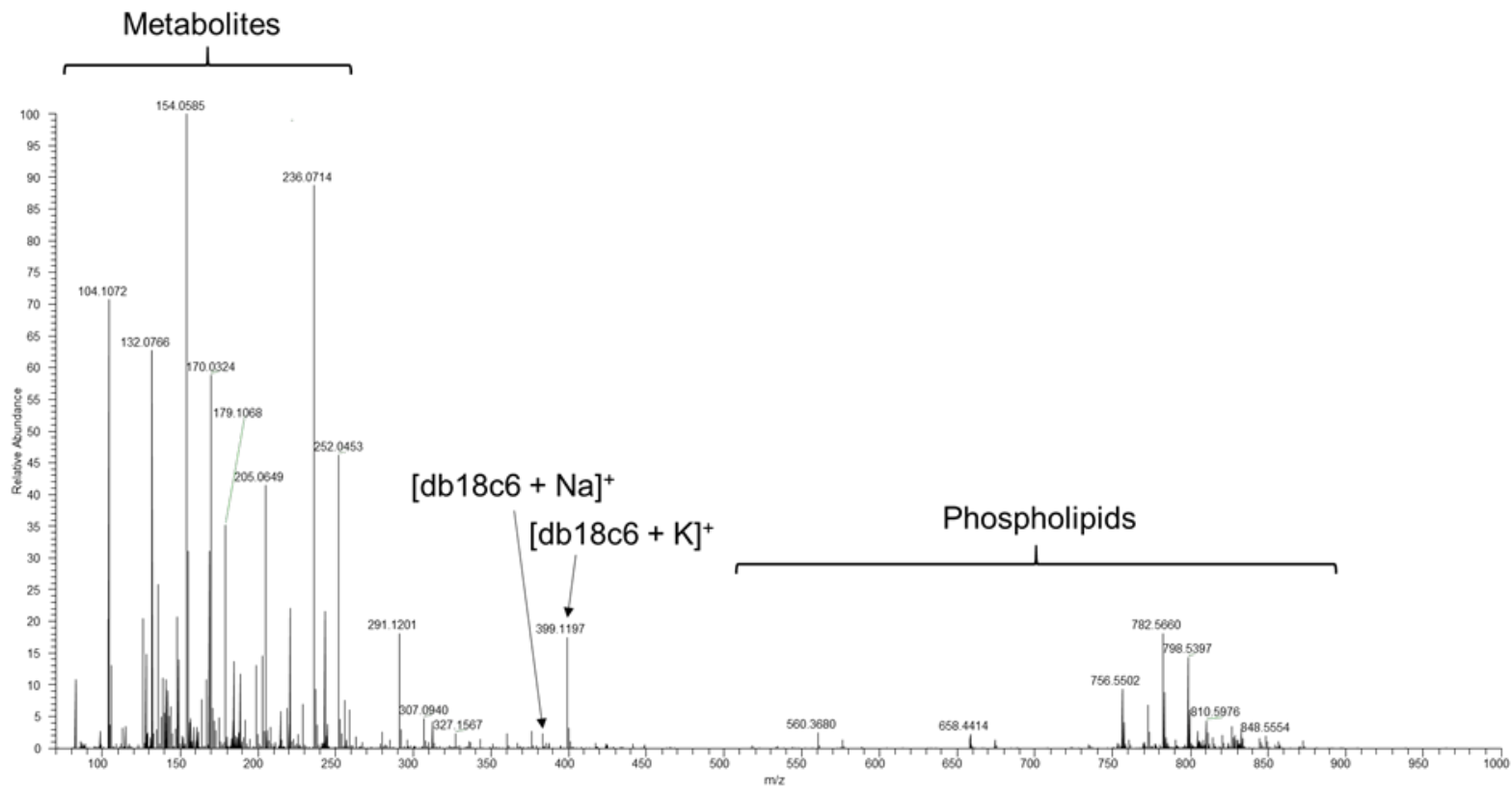

Figure S3. Mass spectrum obtained during db18c6 doped nano-DESI MSI of MCAO mouse brain tissue section representing one scan event.

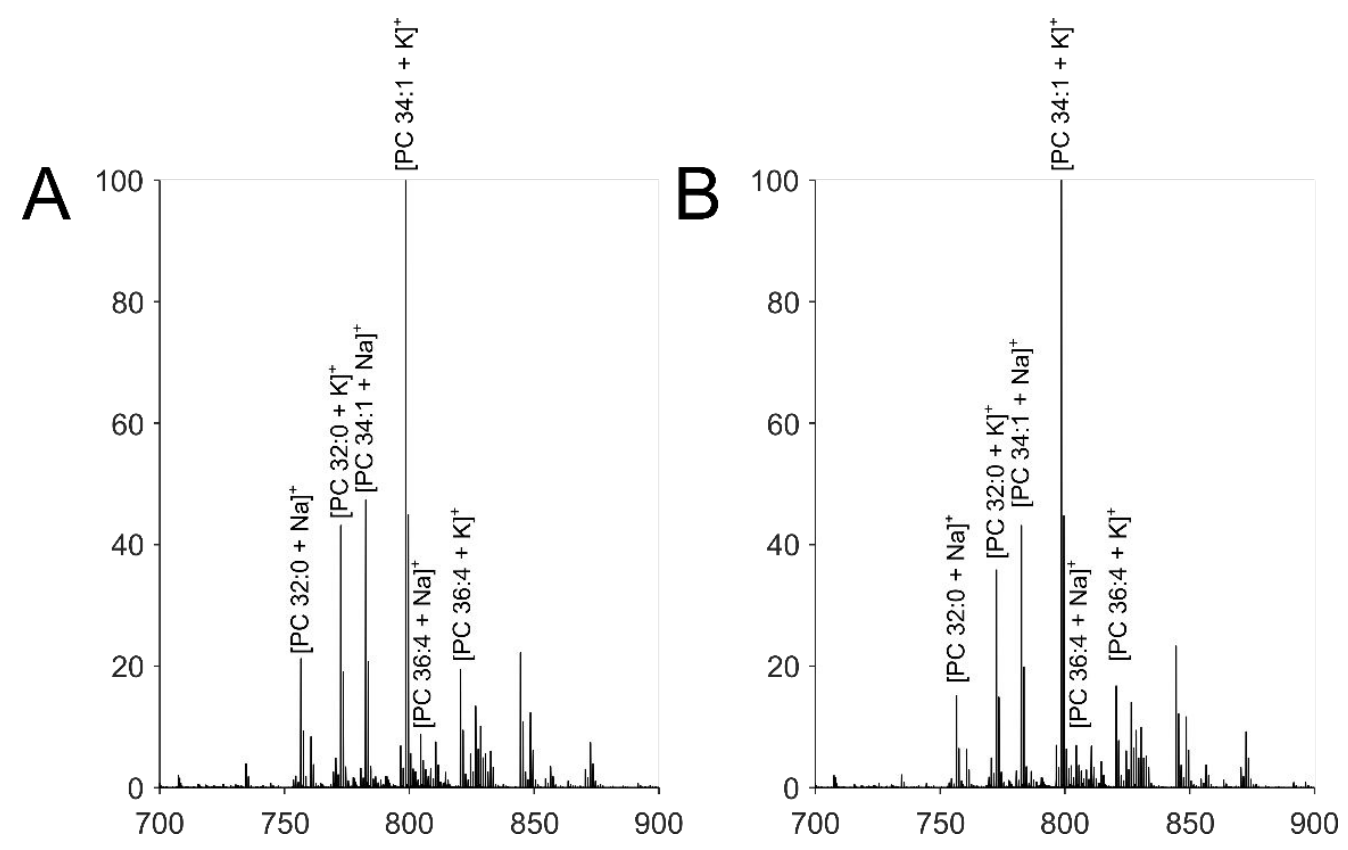

Figure S4. Mass spectra obtained after sampling with the nano-DESI probe from the healthy cortex of a mouse brain tissue section without (A) and with (B) $0.1 \mu \mathrm{M}$ of db18c6 spiked in the solvent. Selected abundant phospholipids are annotated to highlight the similarity among the distribution of $\mathrm{Na}^{+}$and $\mathrm{K}^{+}$adducts between the two spectra. 
Table S2. Binding affinities for $\mathrm{Na}^{+}$and $\mathrm{K}^{+}$for the various crown ethers used. All values obtained from: Izatt, R. M.; Pawlak, K.; Bradshaw, J. S.; Bruening, R. L. Chem. Rev. 1991, 91 (8), 1721-2085

\begin{tabular}{|l|l|l|}
\hline Crown ether & $\log \left(\mathbf{K b}_{\mathbf{N a}^{+}}{ }^{+}\right)$ & $\log \left(\mathbf{K b}_{\mathbf{K}}{ }^{+}\right)$ \\
\hline 12-crown-4 & 2.05 & 1.73 \\
\hline benzo-15-crown-5 & 3.24 & 3.43 \\
\hline 15-crown-5 & 2.94 & 2.96 \\
\hline dibenzo-18-crown-6 & 4.37 & 5 \\
\hline
\end{tabular}
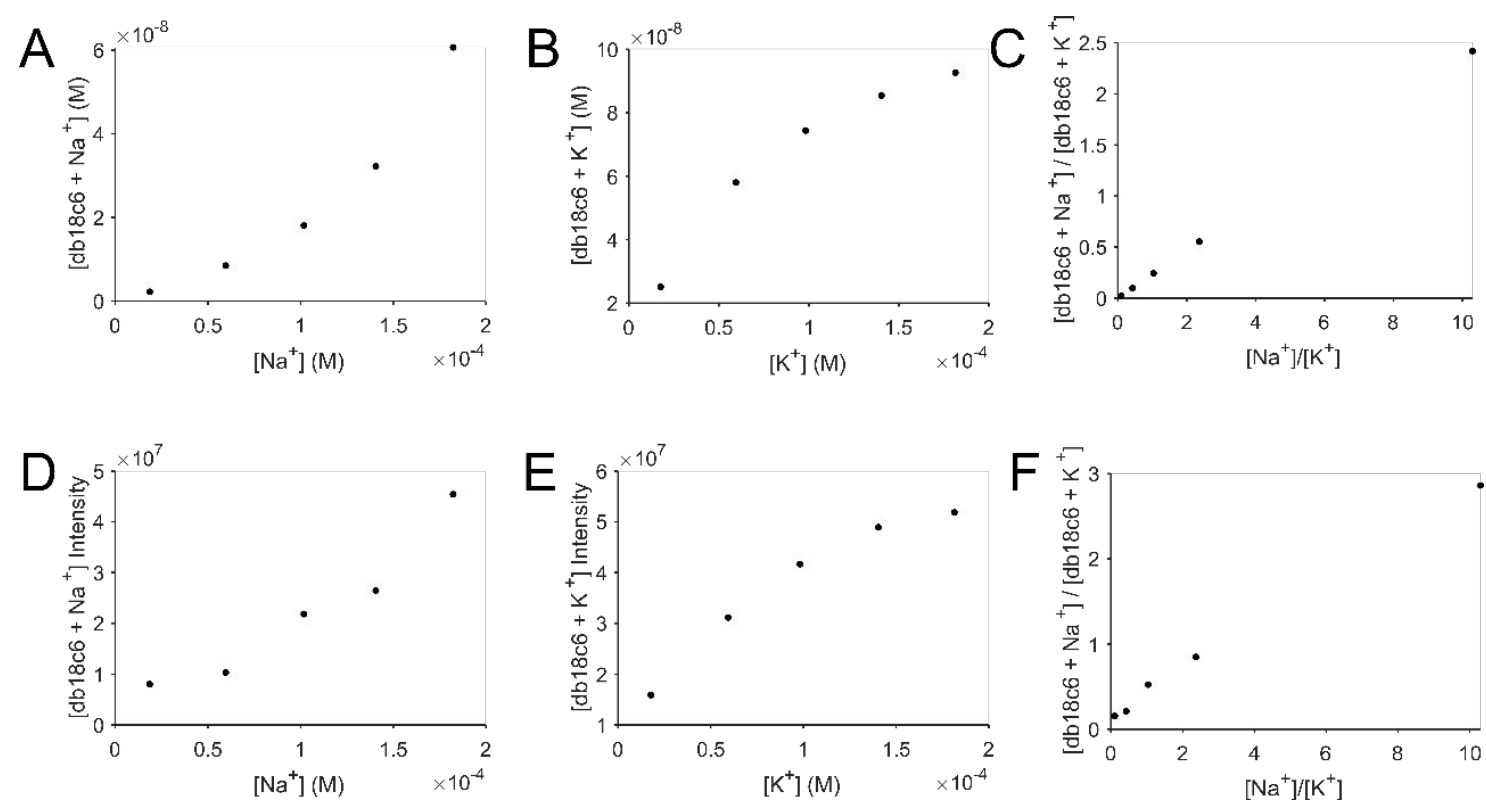

Figure S5. Top row: theoretical equilibrium concentrations of $[\mathrm{db} 18 \mathrm{c} 6+\mathrm{Na}]^{+} \mathrm{vs}\left[\mathrm{Na}^{+}\right](\mathrm{A}),[\mathrm{db} 18 \mathrm{c} 6+\mathrm{K}]^{+} \mathrm{vs}$ $\left[\mathrm{K}^{+}\right](\mathrm{B})$ and their corresponding ratios (C) obtained at total salt concentration of $200 \mu \mathrm{M}$ and various proportions of $\mathrm{Na}$ and $\mathrm{K}(10 \% \mathrm{Na}-90 \% \mathrm{~K}, 30 \% \mathrm{Na}-70 \% \mathrm{~K}, 50 \% \mathrm{Na}-50 \% \mathrm{~K}, 70 \% \mathrm{Na}-30 \% \mathrm{~K}$ and $90 \% \mathrm{Na}-10 \% \mathrm{~K})$. Equilibrium concentrations of the complexes were obtained by solving simultaneous equilibrium equations (see section "Calculation of theoretical equilibrium concentrations for crown ether adducts with $\mathrm{Na}^{+}$and $\mathrm{K}^{+}$" for details) in a system where both $\mathrm{Na}^{+}$and $\mathrm{K}^{+}$are present simultaneously and the crown ether concentration was $0.1 \mu \mathrm{M}$. Bottom row: Experimental data (mass spectrometric intensities) of $[\mathrm{db} 18 \mathrm{c} 6+\mathrm{Na}]^{+}$vs $\left[\mathrm{Na}^{+}\right](\mathrm{D}),[\mathrm{db} 18 \mathrm{c} 6+\mathrm{K}]^{+}$vs $\left[\mathrm{K}^{+}\right](\mathrm{E})$ and their corresponding ratios $(\mathrm{F})$ obtained at total salt concentration of $200 \mu \mathrm{M}$ and various proportions of $\mathrm{Na}^{+}$and $\mathrm{K}^{+}(10 \% \mathrm{Na}-90 \% \mathrm{~K}, 30 \% \mathrm{Na}-70 \%$ $\mathrm{K}, 50 \% \mathrm{Na}-50 \% \mathrm{~K}, 70 \% \mathrm{Na}-30 \% \mathrm{~K}$ and $90 \% \mathrm{Na}-10 \% \mathrm{~K}$ ). All solutions were analyzed with direct infusion ESI-MS and a constant crown ether concentration of $0.1 \mu \mathrm{M}$.
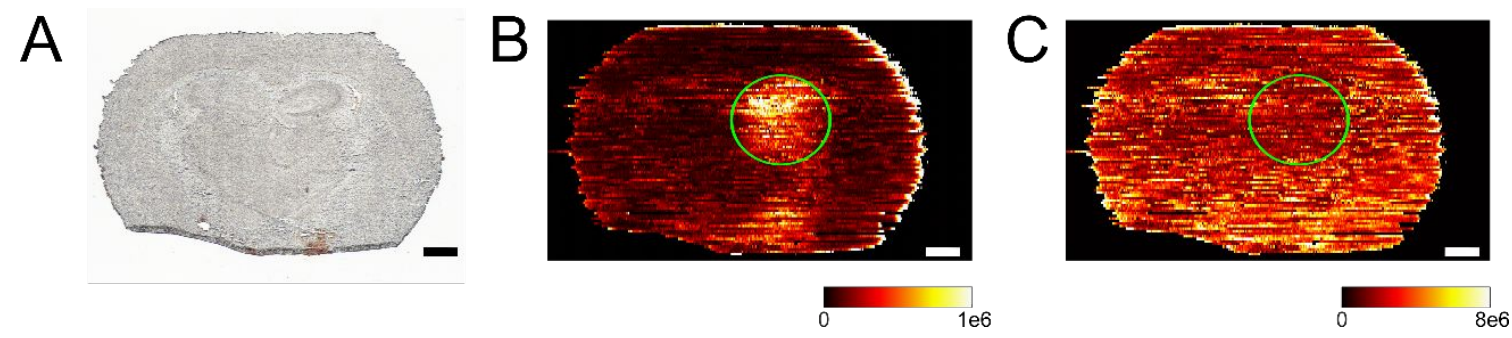

Figure S6. A) Optical image of MCAO mouse brain tissue section. B) Ion image of $[\mathrm{db} 18 \mathrm{c} 6+\mathrm{Na}]^{+}$. C) lon image of $[\mathrm{db} 18 \mathrm{c} 6+\mathrm{K}]^{+}$. Scaling has been adjusted for visualization of less intense features. Only tissue related pixels are shown, as described in the main text. Green circles indicate the damaged area. Scale bars show 1 $\mathrm{mm}$. 
Table S3. Concentrations of $\mathrm{Na}^{+}$and $\mathrm{K}^{+}$for the various total salt conditions tested and for the different proportions of $\mathrm{Na}^{+}$and $\mathrm{K}^{+}$in each solution analyzed with pneumatically assisted nano-DESI.

\begin{tabular}{|c|c|c|c|c|c|c|c|c|c|c|}
\hline \multirow[b]{3}{*}{$\begin{array}{l}\text { Total salt } \\
\text { concentration } \\
(\mu \mathrm{M})\end{array}$} & \multicolumn{10}{|c|}{$\mathrm{Na}^{+}$and $\mathrm{K}^{+}$concentration $(\mu \mathrm{M})$ in each solution } \\
\hline & \multicolumn{2}{|c|}{$\begin{array}{l}10 \% \mathrm{Na}^{+} \\
90 \% \mathrm{~K}^{+}\end{array}$} & \multicolumn{2}{|c|}{$\begin{array}{c}30 \% \mathrm{Na}^{+} \\
70 \% \mathrm{~K}^{+}\end{array}$} & \multicolumn{2}{|c|}{$\begin{array}{c}50 \% \mathrm{Na}^{+} \\
50 \% \mathrm{~K}^{+}\end{array}$} & \multicolumn{2}{|c|}{$\begin{array}{c}70 \% \mathrm{Na}^{+} \\
30 \% \mathrm{~K}^{+}\end{array}$} & \multicolumn{2}{|c|}{$\begin{array}{c}90 \% \mathrm{Na}^{+} \\
10 \% \mathrm{~K}^{+} \\
\end{array}$} \\
\hline & $\mathrm{Na}^{+}$ & $\mathrm{K}^{+}$ & $\mathrm{Na}^{+}$ & $\mathrm{K}^{+}$ & $\mathrm{Na}^{+}$ & $\mathrm{K}^{+}$ & $\mathrm{Na}^{+}$ & $\mathrm{K}^{+}$ & $\mathrm{Na}^{+}$ & $\mathrm{K}^{+}$ \\
\hline 300 & 30 & 270 & 90 & 210 & 150 & 150 & 210 & 90 & 270 & 30 \\
\hline 500 & 50 & 450 & 150 & 350 & 250 & 250 & 350 & 150 & 450 & 50 \\
\hline 700 & 70 & 630 & 210 & 490 & 350 & 350 & 490 & 210 & 630 & 70 \\
\hline 900 & 90 & 810 & 270 & 630 & 450 & 450 & 630 & 270 & 810 & 90 \\
\hline 1100 & 110 & 990 & 330 & 770 & 550 & 550 & 770 & 330 & 990 & 110 \\
\hline
\end{tabular}

Table S4. Predicted and experimentally determined adduct intensity ratios and \% bias of the predictions for unknown adduct intensity ratios using the linear regression line experimentally determined by analyzing neat solutions using direct infusion ESI-MS in Figure S8.

\begin{tabular}{|r|r|r|}
\hline $\begin{array}{l}\text { Predicted } \\
{\left[\mathrm{Na}^{+}\right] /\left[\mathrm{K}^{+}\right]}\end{array}$ & $\begin{array}{l}\text { Experimentally determined }\left[\mathrm{Na}^{+}\right] /\left[\mathrm{K}^{+}\right](\mathbf{\pm} \\
\text { one standard deviation) }(\mathbf{n}=\mathbf{3})\end{array}$ & \% Bias \\
\hline 0.24 & $0.25( \pm 0.08)$ & 4.2 \\
\hline 0.71 & $0.65( \pm 0.01)$ & -8.5 \\
\hline 4.43 & $5.02( \pm 0.58)$ & 13.3 \\
\hline
\end{tabular}



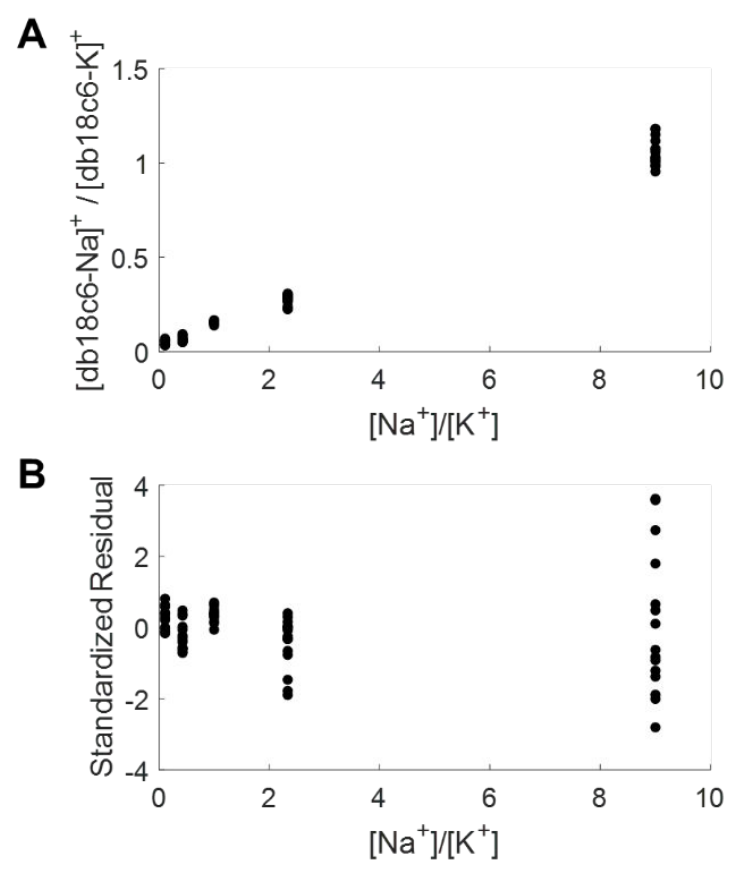

Figure S7. A) $\mathrm{Na}^{+} / \mathrm{K}^{+}$adduct intensity ratio of $\mathrm{db} 18 \mathrm{c} 6$ versus $\left[\mathrm{Na}^{+}\right] /\left[\mathrm{K}^{+}\right]$at various total salt concentrations (see main text for details). B) Standardized residuals versus $\left[\mathrm{Na}^{+}\right] /\left[\mathrm{K}^{+}\right]$obtained after ordinary least squares regression on the data shown in $\mathrm{A}$.

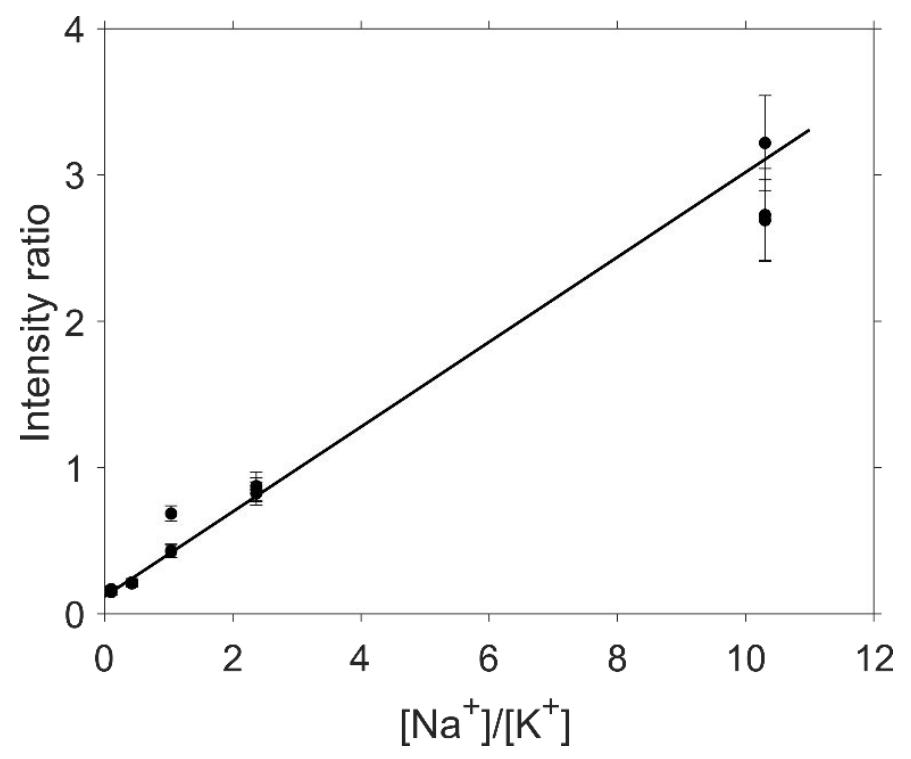

Figure S8. Linear regression of $\mathrm{Na}^{+} / \mathrm{K}^{+} \mathrm{db} 18 \mathrm{c} 6$ adduct intensity ratio experimentally obtained with direct infusion ESI-MS to predict the adduct intensity ratios of unknown solutions in Table S4. Total salt of neat solutions with various $\left[\mathrm{Na}^{+}\right] /\left[\mathrm{K}^{+}\right](0.10$, $0.42,1.04,2.36$ and 10.3 ) at total salt concentration $200 \mu \mathrm{M}$ dissolved in methanol. All solutions contained $0.1 \mu \mathrm{M}$ of $\mathrm{db} 18 \mathrm{c} 6$ and were analyzed in triplicates. Fitted line was obtained with weighted least squares with $1 / \sigma^{2}$ was used as weighting. The equation of the line is $y=0.29 x+0.12$. 

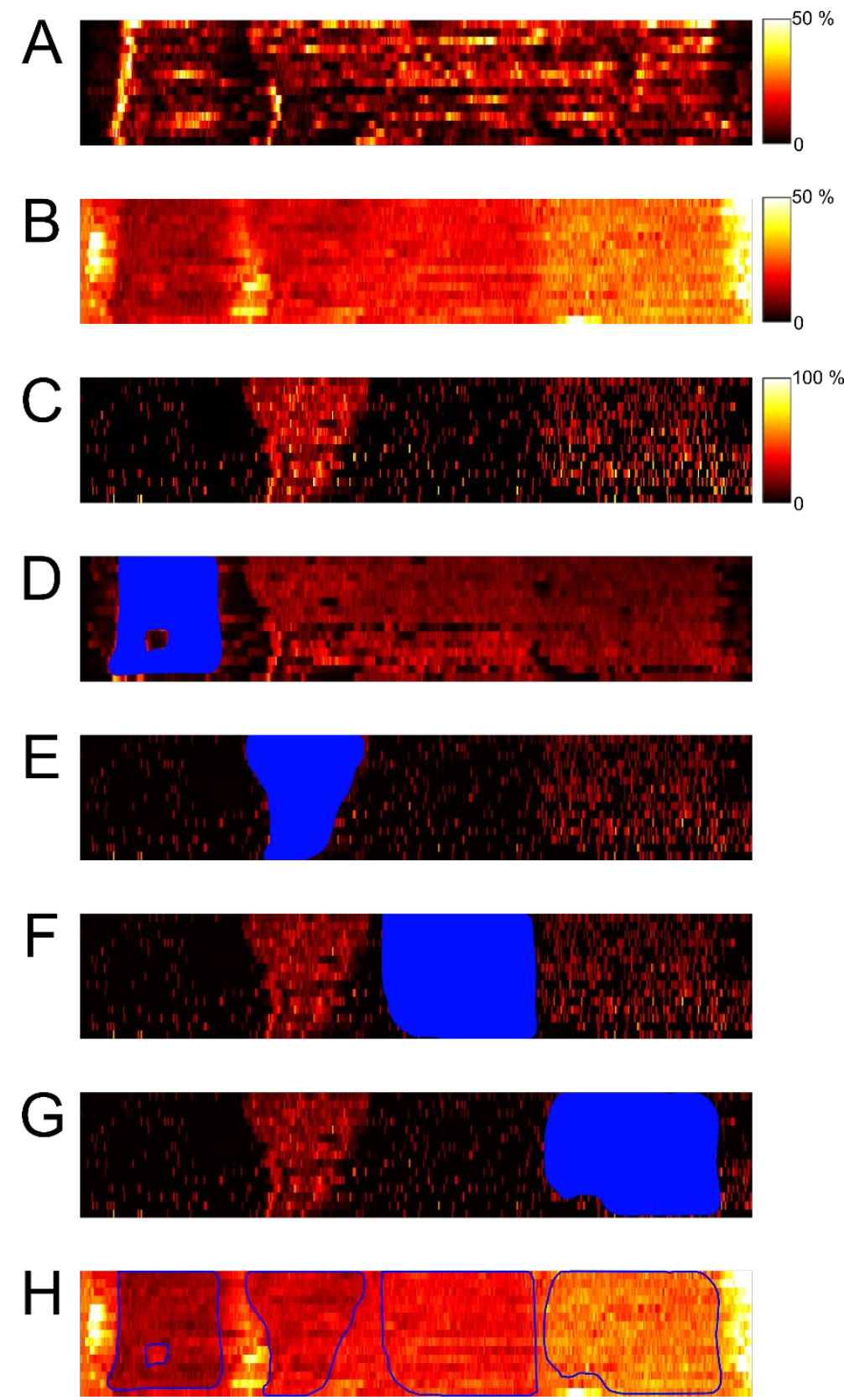

Figure S9. A) lon image of endogenous [LPC 16:0 + Na] ${ }^{+}$normalized to [LPC 19:0 $+\mathrm{Na}]^{+}$in the mimetic tissue model spiked with $\mathrm{NaCl}$. B) $\mathrm{Na}^{+} / \mathrm{K}^{+}$adduct intensity ratio image of $\mathrm{db} 18 \mathrm{c} 6 \mathrm{C}$ ) Composite ion image of [enalapril $+\mathrm{K}]^{+}$and [GABA- ${ }^{15} \mathrm{~N}$ $+\mathrm{Na}^{+}$spiked in the second and fourth layer of the mimetic tissue model, respectively. D) ROI selection of the first layer $\left(0 \mu \mathrm{mol} \mathrm{Na} \mathrm{Na}^{-1}\right)$ based on the distribution of endogenous [creatine $+\mathrm{K}]^{+}$. E) ROI selection of the second layer $\left(20 \mu \mathrm{mol} \mathrm{Na} \mathrm{Na}^{-1}\right)$ based on the image shown in C. F) ROI selection of the third layer $\left(50 \mu \mathrm{mol} \mathrm{Na} \mathrm{g}^{-1}\right)$ based on the image shown in C. G) ROI selection of the fourth layer $\left(90 \mu \mathrm{mol} \mathrm{Na} \mathrm{g}^{-1}\right)$ based on the image shown in $\mathrm{C}$. $\left.\mathrm{H}\right) \mathrm{Na}^{+} / \mathrm{K}^{+}$adduct intensity ratio image of $d b 18 c 6$ with all $R O$ I selections depicted in panels D-G combined. 


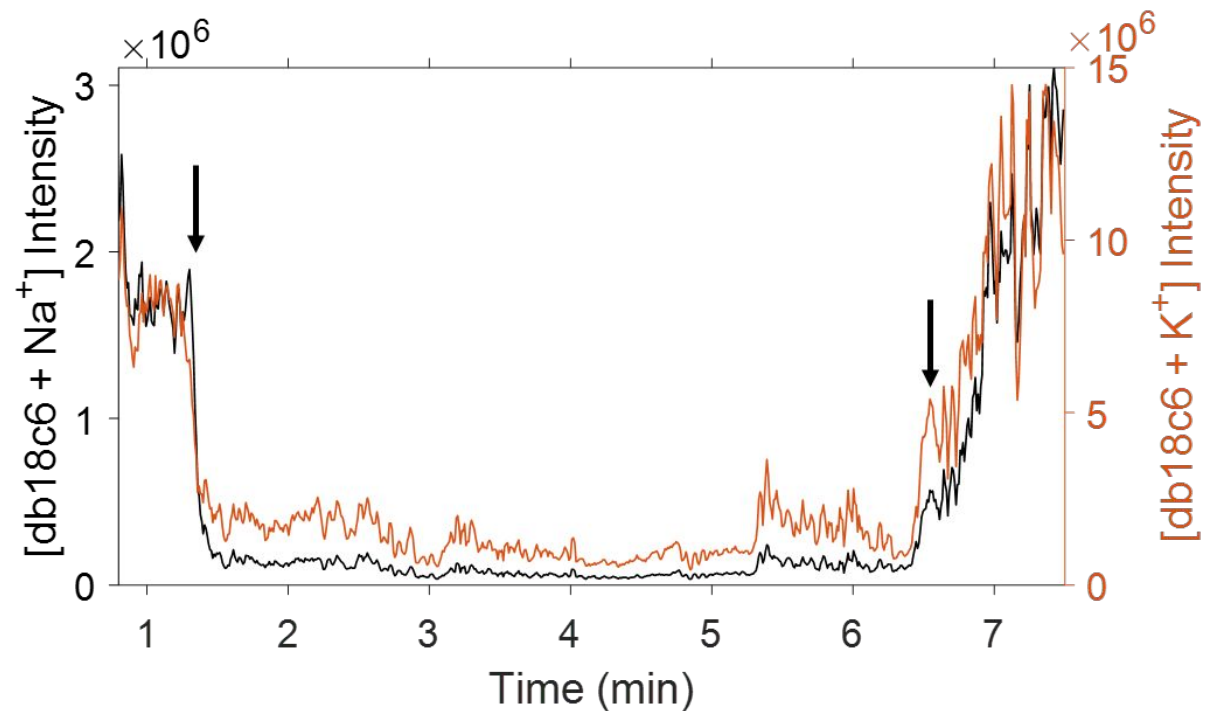

Figure S10. Mass spectrometric intensities of $[\mathrm{db} 18 \mathrm{c} 6+\mathrm{Na}]^{+}$(black line, left axis) and $[\mathrm{db} 18 \mathrm{c} 6+\mathrm{K}]^{+}$(orange line, right axis) when conducting surface sampling from rat brain tissue section. The area between the arrows indicates the tissue surface while outside the arrows the probe was sampling from the glass slide surface. Data were smoothed with a moving average $(n=3)$.

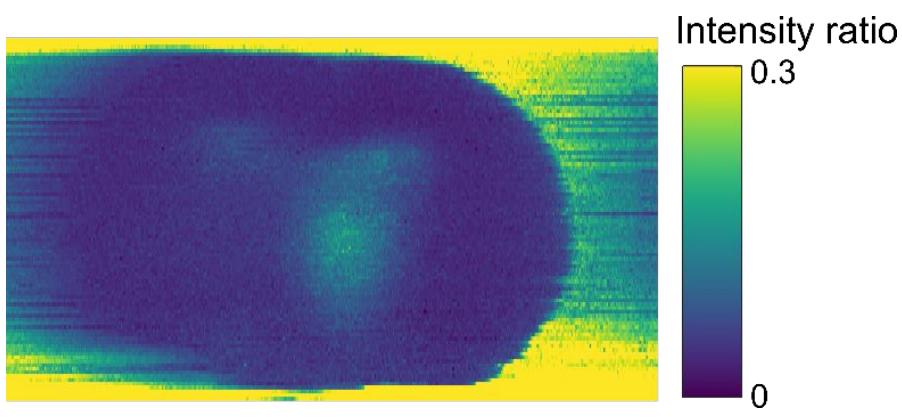

Figure S11. $\mathrm{Na}^{+} / \mathrm{K}^{+}$adduct intensity ratio image of $\mathrm{db} 18 \mathrm{c} 6$ obtained after nano-DESI MSI of MCAO mouse brain tissue section. The image shown here is unprocessed, i.e. all pixels are shown (both glass and tissue) compared to the image shown in Figure $4 \mathrm{~B}$ where only tissue pixels are shown. The data acquisition was done by sampling from right to left. The intensity ratio is not constant throughout the glass slide since the high amount of $\mathrm{K}^{+}$extracted from the tissue is not immediately rinsed away and is carried over to the next acquired line. 


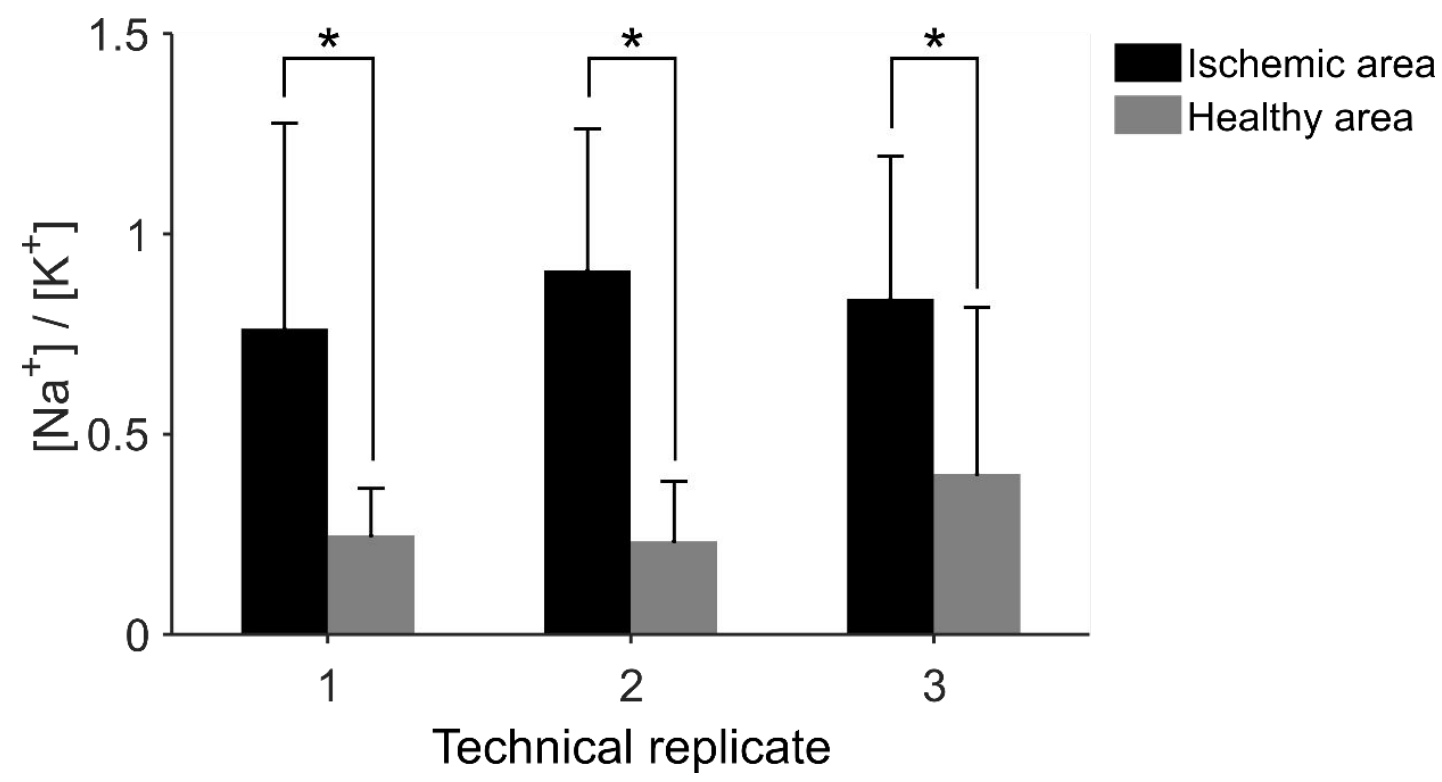

Figure S12. Average $\left[\mathrm{Na}^{+}\right] /\left[\mathrm{K}^{+}\right]$obtained through ROI analysis of three independently analyzed MCAO mouse brain tissue sections. Error bars represent one standard deviation for each average (pixel-to-pixel variation). Statistical significance $\left({ }^{*} p<0.05\right)$ between the healthy and ischemic area of each replicate was assessed using a two-tailed t-test.

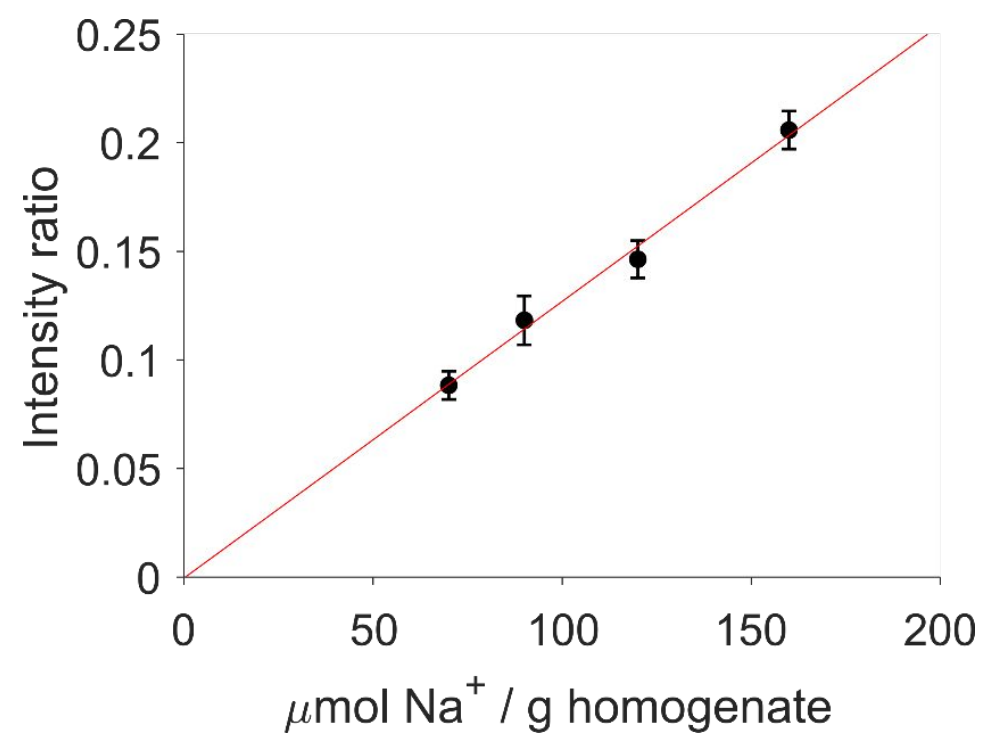

Figure S13. Calibration line obtained from the $\mathrm{Na}^{+}$spiked mimetic tissue model showing the $\mathrm{Na}^{+} / \mathrm{K}^{+}$adduct intensity ratio of $\mathrm{db} 18 \mathrm{c} 6$. Each $\mathrm{x}$-axis point represents the $\mathrm{Na}^{+}$concentration in each layer. The concentration in the non-spiked layer (first point) was determined as described in the main text, through extrapolation from the standard curve of Figure $3 \mathrm{C}$. Each $\mathrm{x}$-axis point has been shifted by the concentration of the non-spiked homogenate $\left(70 \mu \mathrm{mol} \mathrm{Na} \mathrm{g}^{-1}\right)$. Red line indicates linear fit through the data points with equation $y=$ $0.00127 x-0.000346$. Error bars show one standard deviation for each average intensity ratio. 